\title{
Cause and effect of accounting information system: A study in national Zakat management organization
}

\author{
Adeh Ratna Komala* \\ University of Computer, Bandung, Indonesia
}

\author{
Index Terms \\ Organizational culture \\ Accounting information system \\ Zakat organization forum
}

Received: 25 January 2017

Accepted: 4 March 2017

Published: 21 April 2017

\begin{abstract}
Cultural organizations can improve the effectiveness of accounting information systems. The effectivess of accounting information system can affect the effectiveness of accounting information. The phenomenon that occurs in an organization in Indonesia shows the accounting information system has not been qualified so the accounting information has not been qualified either. This study was conducted to seek the truth through testing that shows the influence of organizational culture on the effectiveness of accounting information systems that have an impact on the effectiveness of accounting information. The data which were used were obtained through a survey by distributing a questionnaire to 38 recorded zakat management organizations active in Zakat Organizations Forum (FOZ), processed statistically using SEMPLS. The research method used explanatory research method, to get the basic answers of cause and effect by analyzing the causes of problems in the effectiveness of accounting information systems and the effectiveness of accounting information. The results showed the issue on the effectiveness of accounting information that has not happened because it has not been the effectiveness of accounting information system. The accounting information systems have not been optimal because it has not been the effectiveness of organizational culture.
\end{abstract}

(C) 2017 The Author(s). Published by TAF Publishing.

\section{INTRODUCTION}

"Accounting information is that a sub set of information that is expressed mainly in financial (money) terms" (Clarke, 2002:9). Xu (2009:1) said that the effectiveness of accounting information is a competitive advantage for the organization. With the quality of accounting information, organization will be superior in decision-making compared to its competitors (Laudon \& Laudon, 2008:14). Accurate, timely, relevant and complete are characteristics of the information quality, (McLeod \& Schell, 2007:35). The potential of zakat in Indonesia in 2015 is 217 trilion rupiahs, but the amount collected is only 3.7 trilion rupiahs (Junaidi, 2016). The phenomenon that occurs in zakat management organization is expressed by Chaidar, Baramuli \& Irfan (2011) and Azzumardi (2011) that the accountability of account- ing information in zakat organizations has not been good. If the accounting information is bad then organization will be in chaos (Strong, Lee \& Wang, 2007:38) and when the accounting information in organization is in good quality, then the organization can work well (Salehi, Rostami \& Mogadam, 2010). Laudon \& Laudon (2008:7) said that the information quality is generated by the effectiveness of accounting information system. The phenomenon that occurs in zakat management organization is expressed by Nana (2011) that among the major problems that is faced by zakat management organization, one of the problems is information systems, because most zakat management organizations do not understand the importance of information systems to improve the information quality and the organization's performance. The effectiveness of informa-

\footnotetext{
${ }^{*}$ Corresponding author: Adeh Ratna Komala

${ }^{\dagger}$ Email: adeh.rk@gmail.com
} 
tion system is an information system that presents ease of usefulness (Moller \& Charles \& Sohail, 2011:81), adaptability (Tavana, 2011:1) and integration (Norman, 2007:20).

According to Claver, Llopis, Reyes Gonzalez \& Gascó (2001) organizational culture is associated with accounting information systems, which can form the organizational culture and provide guidance in the implementation of the effectiveness of accounting information systems in organizations. Further it is said that organizational culture is measured by artifacts (Colquit, Lepine \& Wesson, 2011:559-561), values (Mcshane \& Glinow, 2010:416) and basic assumptions (Ivancevich, Konopaske \& Michael, 2011:41). Then it is grouped by type, they are culture of clan, adhocracy, market and hierarchy (Nevizond, 2007:32-41).

\section{LITERAT URE REVIEW \\ Organizational Culture}

The culture of organization is a set of values, beliefs, behaviors, habits, and attitudes that help a member of organization in understanding the principles which are espoused by the organization how it does everything and what it considers important (Griffin \& Moorhead, 2003:162). Colquit et al. (2011:528) said that culture of organization is a social knowledge in an organization on the rules, norms and values that shape the attitudes and behaviors of employees. Kreitner \& Kinicki (2009:65) said that organizational culture is the shared values and beliefs underlying "organizational identity". The culture of organization is a set of beliefs, values, rituals, events, myths and specialized terminology which is the result of a common identity and sense of community in an organization. In this study, the instrument used to describe the organizational culture profile is Organizational Culture Assessment Instrument (OCAI), it is an instrument that highlights the main points of the dimensions and attributes of organizational culture (Nevizond, 2007:39). The theoretical model is known as the Competing Values Framework, it is one of the concepts that can be used to diagnose the organizational culture which is based on the dominant characteristic phenomenon of the organization, a model of managerial and leadership ways of managing employees, organization adhesives, the strategy adopted and the criteria for success (Cameron \& Quinn, 1999 ). Based on the type, culture is divided into culture clan, adhocracy, market and hierarchy (Nevizond, 2007: 32-41).

\section{The Effectiveness of Accounting Information Systems}

Weyandt, Kimmel \& Kieso, (2010:199) said that the accounting information system is a system that produces information from data transaction. Then Gellinas, Ulrich, Dull \& Wheeler (2012:14) said that the accounting information system is a component of management information systems.

As for Romney \& Steinbart (2012:6) they define a system that collects, records, stores, and processes the data to generate information is an accounting information system. In detail Susanto (2004:72) defines that system of accounting information is an integration of sub-systems which are interconnected with each other to process transaction data related to financial problem into financial information. In this study the effectiveness of information systems dimensions are ease of use that should be clear and understandable usefulness means that it can assist the user in doing his job (Moller et al., 2011:81), adaptability which emphasizes the ability to manage internal and external changes (Tavana, 2011:1) and integrated means integrated information system on the basic parts of the system to achieve better function in line with expectations (Norman, 2007:20).

\section{The Effectiveness of Accounting Information}

Accounting information which is disclosed by Clarke (2002:9) that information of accounting is a set of information that is expressed in financial terms. Information of accounting is used to plan and control performance. Belkaoui (2004:213) said that information of accounting is essentially monetary and quantified. Information of accounting is quantitative, formal, structured, audited, numerical and past-oriented.

The effectiveness of information is information that is suitable for the user, wherein the information available has distinctive features that meet or even exceed the expectations of users (Kahn, Strong \& Wang, 2002:185). The dimensions of accounting information which are used in this study are accurate that means the information should reflect the actual situation, timely means that the information should be available when it is needed, relevant means that the information provided must be suitable with as required (if appropriate) and complete information should be fully given according to the needs of users in an effort to make the decision (Mcleod \& Schell, 2007:35).

\section{Framework}

The effectiveness of accounting information systems is influenced by organizational culture

O'Brien \& Marakas, (2009:17) said that effectiveness of 
information systems is formed by increasing the organizational culture. It is very important to understand the culture to assess the information system of which the culture at every level, including national, organization's and group's culture can influence the effectiveness of information systems within a company (Leidner \& Kayworth, 2006). Batool (2011) said that organizational culture is one of the factors that influence the effectiveness of information systems. Salehi \& Abdipour (2011) explain that the research results are done to identify some of the inhibiting factors which form the high quality of information systems and one of which is mentioned as 19 percent of the inhibiting factors that is the organizational culture. The same thing is said by Allen et al. (2004) who found that organizational culture is one factor that inhibits the forming of the effectiveness of information system. The next Komala (2012) said that organizational culture significantly influences system of accounting information. Based on description it can be said that the organizational culture influences the system of accountig information.

\section{The effectiveness of accounting information is influenced by the ffectiveness of accounting information systems}

Heidmann (2008:80) said that the system quality produces quality of information and it reflects the information processing system. Hall (2011:15) said that user requires the information that is generated by information system. Gellinas et al. (2012:14) revealed the effectiveness of the information available through such systems. Romney \& Steinbart (2012:6) said that an accounting information system is a system that collects, records, stores, and processes the data to produce information.

Next Arens, Elder \& Beasley (2010:7) said that organizations should develop a system of information to ensure that the events of economic entities are noted timely and reasonably for the preparation of information. Salehi $e t$ al. (2010) said that the accounting information system's quality improves the accounting information's quality, the research results reveal that there is a gap between the information systems that should be and the actual ones. The quality of accounting information is affected by the quality of accounting information system, (Komala, 2012; Kurniawati \& MeilianaIntani, 2016; Alfian \& Tresna, 2017). Next Sajady, Dastgir \& Nejad (2008) explains that the effectiveness of accounting information systems can improve the effectiveness of accounting information. The framework of this study is as follows:

H1: Organizational Culture influences the Effectiveness of
Accounting Information Systems.

H2: The Effectiveness of Accounting Information System influences the Effectiveness of Accounting Information.

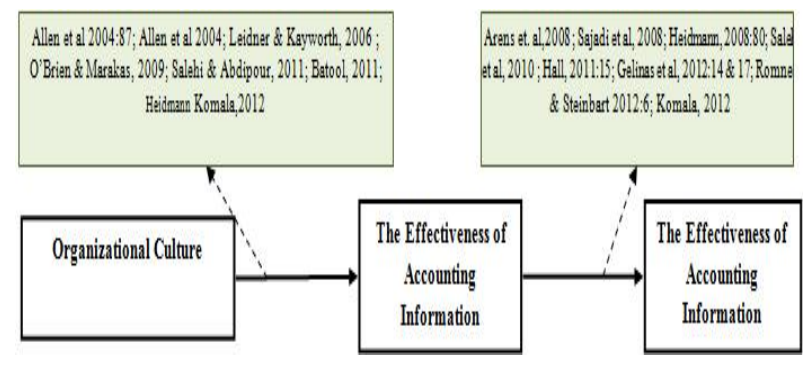

FIGURE 1. The framework

\section{RESEARCH METHOD}

This research used the descriptive and explanatory method. The target population of this research was Zakat Management Organization that is registered in Zakat Organization Forum. The samples were obtained as much as $38 \mathrm{OPZ}$. The reasons to set the population from Zakat Management Organization is an organization which is related to public funds, where the information system in OPZ that generates the information is still not qualified, while the funds raised are public funds that must be accounted for. The method used in data collection was survey method with a questionnaire sent by mail and email. Data analysis was carried out through (i) descriptive analysis to explain the variables' characteristics that were studied in order to support troubleshooting to obtain advice operationally; (ii) the analysis through structural equation modeling (Structural Equation Model-SEM) in order to answer the problem formulation, and the hypothesis.

\section{RESULTS AND DISCUSSION}

\section{Descriptive Analysis of Organizational Culture}

In the zakat management organization although it is a nonprofit organization it is still working to be able to explore the large enough zakat potential so that it focuses on zakat transaction. The efforts to attract muzakki would be a challenge. Among the zakat management organizations, there is competition with each other to gain the trust of its muzakki. This certainly becomes a motivation for every zakat management organization to market zakat programs that can make its mustahik independent and increase the public trust, especially the muzakki. It is intended that in the future the zakat mustahik who are guided will be the muzakki who are potential for the community. Market culture is very pronounced in zakat management organization which is formed based on public self-service as it will com- 
pete floating mass. As for zakat management organization which is under the name of a company, its muzakki target is more definite, because the company's employees are its main muzakki. But the organization also must still strive to maintain its muzakki loyalty because there is no obligation for employees to be the remaining muzakki under the auspices of the company. It is strongly associated with the trust of its muzakki on zakat management organizations.

TABLE 1. The recapitulation score of respondents to organizational culture variable

\begin{tabular}{|c|c|c|c|c|c|c|c|c|c|c|c|c|c|}
\hline \multirow[t]{2}{*}{ No } & \multirow[t]{2}{*}{ Indicator } & \multicolumn{10}{|c|}{ Respondents } & \multirow[t]{2}{*}{ Mean Score } & \multirow[t]{2}{*}{ Criteria } \\
\hline & & $\mathrm{F}$ & $\mathrm{B}$ & $F$ & B & $\mathrm{F}$ & B & $F$ & B & $F$ & B & & \\
\hline 1 & Philosophy & 17 & 85 & 75 & 300 & 10 & 30 & 9 & 18 & 3 & 3 & 3.82 & Market \\
\hline \multirow[t]{2}{*}{2} & Stability & 16 & 80 & 59 & 236 & 27 & 81 & 8 & 16 & 4 & 4 & 3.66 & Market \\
\hline & & & & Basic Assumption & & & & & & & & 3.74 & Market \\
\hline 3 & Competence & 32 & 160 & 27 & 108 & 39 & 117 & 14 & 28 & 2 & 2 & 3.64 & Market \\
\hline \multirow[t]{2}{*}{4} & Aggressiveness & 18 & 90 & 19 & 76 & 28 & 84 & 28 & 56 & 21 & 21 & 2.87 & Adhocracy \\
\hline & & & & Value & & & & & & & & 3.25 & Market \\
\hline 5 & Organizational climate & 14 & 70 & 40 & 160 & 42 & 126 & 11 & 22 & 7 & 7 & 3.38 & Market \\
\hline \multirow[t]{3}{*}{6} & The distribution of power and authority & 18 & 90 & 51 & 204 & 31 & 93 & 7 & 14 & 7 & 7 & 3.58 & Market \\
\hline & & & & Artefact & & & & & & & & 3.48 & Market \\
\hline & & & & Grand mean & & & & & & & & 3.49 & Market \\
\hline
\end{tabular}

Maintaining muzakki loyalty is certainly the next homework for the zakat organizations, because the muzakki who are already satisfied with the services, programs and operations will strive to entrust their zakat to zakat management organizations of which their survival depends on the level of public trust (muzakki). Indicator of 'aggressiveness' seems to be the type of adhocracy culture that is a culture where the organization member individually is able to take risks, has the value of innovation and entrepreneurship. It is pretty good when it is viewed from the products produced in the form of zakat program. It means that employees in zakat management organizations innovate enough to create a zakat program. But it is needed to be more motivated in order to reach the market culture so that such innovative results program can be marketed to the muzakki. The success in marketing zakat program can be seen from the increasing public confidence by seeing an increasing number of muzakki who do zakat in zakat management organization. The muzakki who are collected are expected to be able to explore the zakat potential so that the achievement can be optimized.

\section{Analysis of Accounting Information Systems}

The calculation results of the grand mean score for Accounting Information Systems at 3.48 (on a scale of 3-4 interval) mean that the System of Accounting Informatian on zakat management organizations is on the criteria good enough.

ISSN: 2414-309X

DOI: $10.20474 /$ jabs-3.2.2
This shows that the Accounting Information System on zakat management organizations indicates that the functional integration (application) is the biggest obstacle in zakat management organizations. Most of the zakat management organizations use the system which is not fully integrated yet. The ATM and internet banking services which are offered by mostly zakat management organizations in fact are still separate from the internal systems used in the organization. The checking account which is the information from the bank is used as input data for the system running in the organization. It is said further that in order to integrate the applications, functions running are constrained in the muzakki. The muzakki consistency in doing zakat in the same zakat management organization has not been consistent. The amount of zakat issued every month is not the same. In addition, there are many Muslims who consider that zakat is not an obligation that must be fulfilled like any other worship such as sholat. So the intensity of the time was irregular. This condition becomes an obstacle for zakat management organization to create a system that is completely integrated from its application functions. Under such condition, automatically its application functional specification will be complex. The response picture of the research sample to each item on the statement of Accounting Information System variables is shown in the following table. There are four dimensions to the effectiveness of Accounting Information Systems variable, they are Ease of Use, Usefulness, Adaptability, and Integration.

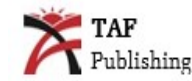


TABLE 2 . The recapitulation score of respondents to effectiveness of accounting information systems variable

\begin{tabular}{|c|c|c|c|c|c|c|c|c|c|c|c|c|c|c|}
\hline \multirow[t]{2}{*}{ No } & \multirow[t]{2}{*}{ Indicator } & \multicolumn{10}{|c|}{ Respondents } & \multirow[t]{2}{*}{$\%$ Actual score } & \multirow[t]{2}{*}{ Mean Score } & \multirow[t]{2}{*}{ Criteria } \\
\hline & & $\mathrm{F}$ & $\mathrm{B}$ & $\mathrm{F}$ & B & $\mathrm{F}$ & B & $\mathrm{F}$ & B & $\mathrm{F}$ & B & & & \\
\hline 7 & Ease to use system & 3 & 15 & 69 & 276 & 32 & 96 & 8 & 16 & 2 & 2 & 71.05 & 3.55 & Enough \\
\hline 8 & & & & Ease of use & & & & & & & & 72.19 & 3.61 & Enough \\
\hline 9 & Assist users in performing their duties & 24 & 120 & 74 & 296 & 10 & 30 & 5 & 10 & 1 & 1 & 80.18 & 4.01 & Good \\
\hline 10 & & & & Usefulness & & & & & & & & 75.18 & 3.76 & Enough \\
\hline 11 & Adapt to technology change & 2 & 10 & 47 & 188 & 37 & 111 & 24 & 48 & 4 & 4 & 63.33 & 3.17 & Enough \\
\hline \multirow[t]{2}{*}{12} & Easy to access & 2 & 10 & 66 & 264 & 31 & 93 & 14 & 28 & 1 & 1 & 69.47 & 3.47 & Enough \\
\hline & & & & Adaptability & & & & & & & & 66.40 & 3.32 & Enough \\
\hline 13 & Integration of components & 1 & 5 & 63 & 252 & 28 & 84 & 18 & 36 & 4 & 4 & 66.84 & 3.34 & Enough \\
\hline
\end{tabular}

Data processed (Komala, 2015)

Descriptive Analysis on the Effectiveness of Accounting Information

The calculation results of grand mean score for the effectiveness of Accounting Information by 3.63 (on a 3-4 scale intervals) mean that the Accounting Information on zakat management organization is in the category of 'good enough'. The gap of $21.39 \%$ is the quantification form of the ideal condition (which is expected), namely the effectiveness of Accounting Information (all respondents answer the scale of 5). The response picture of the sample to each item in the statement of Accounting Information variables is shown in the following table, There are four dimensions to the effectiveness of Accounting Information variable, they are Accurate, Timely, Relevant, and Complete.

TABLE 3 . The recapitulation score of respondents to accounting information variable

\begin{tabular}{|c|c|c|c|c|c|c|c|c|c|c|c|c|c|c|}
\hline \multirow[t]{2}{*}{ No } & \multirow[t]{2}{*}{ Indicator } & \multicolumn{10}{|c|}{ Respondents } & \multirow[t]{2}{*}{$\%$ Actual score } & \multirow[t]{2}{*}{ Mean Score } & \multirow[t]{2}{*}{ Criteria } \\
\hline & & $\mathrm{F}$ & $\mathrm{B}$ & $\mathrm{F}$ & B & $\mathrm{F}$ & B & $\mathrm{F}$ & B & $\mathrm{F}$ & B & & & \\
\hline 15 & Information according to the actual situation & 5 & 25 & 74 & 296 & 20 & 60 & 10 & 20 & 5 & 5 & 71.23 & 3.56 & Enough \\
\hline \multirow[t]{2}{*}{16} & Information free from material error & 4 & 20 & 53 & 212 & 43 & 129 & 7 & 14 & 7 & 7 & 67.02 & 3.35 & Enough \\
\hline & & & & Accurate & & & & & & & & 69.12 & 3.46 & Enough \\
\hline 17 & Information available in times as needed & 7 & 35 & 68 & 272 & 28 & 84 & 7 & 14 & 4 & 4 & 71.75 & 3.59 & Enough \\
\hline \multirow[t]{2}{*}{18} & Frequency of consistent reports & 8 & 40 & 77 & 308 & 18 & 54 & 7 & 14 & 4 & 4 & 73.68 & 3.68 & Enough \\
\hline & & & & Timely & & & & & & & & 72.72 & 3.64 & Enough \\
\hline 19 & Information as needed & 4 & 20 & 80 & 320 & 22 & 66 & 4 & 8 & 4 & 4 & 73.33 & 3.67 & Enough \\
\hline \multirow[t]{2}{*}{20} & Information able to influence decisions & 19 & 95 & 73 & 292 & 12 & 36 & 7 & 14 & 3 & 3 & 77.19 & 3.86 & Enough \\
\hline & & & & Relevant & & & & & & & & 75.26 & 3.76 & Enough \\
\hline 21 & Complete information & 2 & 10 & 83 & 332 & 15 & 45 & 11 & 22 & 3 & 3 & 72.28 & 3.61 & Enough \\
\hline \multirow[t]{3}{*}{22} & Information presented appropriately & 4 & 20 & 86 & 344 & 15 & 45 & 6 & 12 & 3 & 3 & 74.39 & 3.72 & Enough \\
\hline & & & & Complete & & & & & & & & 73.33 & 3.67 & Enough \\
\hline & & & & Grand mean & & & & & & & & 72.61 & 3.63 & Enough \\
\hline
\end{tabular}

The Influence of Organizational Culture on the Effectiveness of Accounting Information Systems

Organizational Culture is hypothesized to influence the effectiveness of Accounting Information Systems. The follow-

ISSN: 2414-309X

DOI: $10.20474 /$ jabs-3.2.2 ing are the results of significance test of these hypotheses through statistical hypothesis as follows:

Ho: Organizational Culture does not influence the Effectiveness of Accounting Information Systems. 
Ha: Organizational Culture influences the Effectiveness of Accounting Information Systems.

TABLE 4. The significance test on the influence of organizational culture on the effectiveness of accounting information systems

\begin{tabular}{llll}
\hline \hline Path Coefficient & T-count & T-critical & Conclusion \\
\hline Conclusion & Conclusion & Conclusion & Conclusion \\
\hline \hline
\end{tabular}

T-count value of path coefficient of the Organizational Culture variable on the effectiveness of Accounting Information Systems which was obtained equals to 2.170 bigger than t-critical, we conclude that the Organizational Cultural has significant influence on the effectiveness of Accounting Information Systems. The direct influence of Organizational Culture on the Effectiveness of Accounting Information Systems is $4.8 \%$ while the indirect influence of Organizational Culture on the Effectiveness of Accounting Information Systems through other exogenous latent variables is $5.3 \%$ so the total amount of the partial influence of Organizational Culture on the Effectiveness of Accounting Information System is $10.1 \%$.

\section{The Influence of the Effectiveness of Accounting Infor- mation Systems on the Effectiveness of Accounting In- formation}

The effectiveness of Accounting Information Systems is hypothesized to influence the effectiveness of Accounting Information. The following are the results of significance test of these hypotheses through statistical hypothesis as follows:

Ho: The Effectiveness of Accounting Information System does not influence the Effectiveness of Accounting Information.

Ha: The Effectiveness of Accounting Information System influences the Effectiveness of Accounting Information.

T-count value of path coefficient on the effectiveness of Accounting Information Systems variable to the effectiveness of Accounting Information was obtained as 5.960 bigger than t-critical. It can be concluded that the effectiveness of Accounting Information Systems has a significant influence on the effectiveness of Accounting Information.

TABLE 5. The significance test on the influence of the effectiveness of accounting information systems on the effectiveness of accounting information

\begin{tabular}{llll}
\hline \hline Path Coefficient & T-count & T-critical & Conclusion \\
\hline 0.629 & 5.960 & 1.96 & Hypothesis accepted \\
\hline \hline
\end{tabular}

ISSN: 2414-309X

DOI: $10.20474 /$ jabs-3.2.2
TABLE 6 . The big influence of the effectiveness of accounting information systems on the effectiveness of accounting information

\begin{tabular}{ll}
\hline \hline Variables & The Influence \\
\hline The Effectiveness of Accounting Information Systems & $39.6 \%$ \\
\hline \hline
\end{tabular}

The big influence of the effectiveness of Accounting Information Systems on the effectiveness of Accounting Information is $(0.629 \times 0.629 \times 100 \%)=39.6 \%$. The results showed that the effectiveness of accounting information systems influences the effectiveness of accounting information with the effect of $39.6 \%$. These results indicate that the effectiveness of information refers to the effectiveness of the output which is produced by information system, better effectiveness of accounting information systems can lead to the achievement of optimal quality of accounting information.

\section{CONCLUSION}

1) The accounting information system which has not been qualified occurs because the organizational culture that had been running is still not optimal.

2) The effectiveness of accounting information systems influences the effectiveness of accounting information. The accounting information that has not been qualified occurs because the effectiveness of accounting information system has not been qualified.

\section{SUGGESTIONS}

1) The aggressiveness in innovating and marketing zakat programs is very necessary to be optimized. Market culture which is the hallmark of OPZ also applies to aggressiveness. $\mathrm{OPZ}$ is a non-profit organization that is not/has not been commonly the choice of work, so the employees who work in this organization must have high integrity to advance OPZ.

2) Related to SIA, the suggestions which are put forward are:

a) To provide hardware, software, procedures, database and communication technology network which is adequate (integrated) to support user needs either as amil, muzakki or mustahik.

b) Zakat management organizations need to optimize the access of communication technology network to any information in the form of zakat program innovation, financial reporting, region mapping and other matters which are related to zakat can be accessed easily.

c) OPZ needs to provide application systems which are adequate and optimally integrated in order to provide max- 
imum services particularly to the muzakki. This becomes particularly necessary when returning to the initial intention to maximize the large zakat potential. To spoil Muzakki in doing zakat is the price that must be paid highly either by force, time, or specially idea.

\section{REFERENCES}

Allen, B., Juillet, L., Miles, M., Paquet, G., Roy, J., \& Wilkins, K. 2004. The organizational culture of digital government: Tech- nology, accountability and shared governance". In A. Pavlichev \& G.D Garson (Eds.), Digital government: Principles and best practices: 78-96: Hershey, USA: Idea Publishing Group.

Alfian \& Tresna, M.G. 2017. The influence of company's age and owner's/manager's education on the use of accounting in- formation in small and medium enterprises. International Journal of Business \& Administrative Studies, 3(2): 64-71.

Arens, A.A., Elder, R.J., \& Beasley, M.S. 2010. Auditing and assurance services: An integrated approach. Upper Saddle River, NJ: Pearson/Printice Hall.

Azzumardi, A. 2011. Revitalisasi Filantropi Islam. URL: goo.gl/VNIyNt. Last accessed on 27 March 2017.

Batool, S. 2011. Analyze the factors that have an influence on the management control system. Research Journal of Finance \& Accounting, 2(3): 48-56.

Belkaoui, A.R. 2004. Accounting theory. Bedford Row, UK: Thomson Learning.

Cameron, K.S., \& Quinn, R.E. 1999. Diagnosing and changing organizational culture. Reading, UK: Addison-Wesley.

Chaidar, S., Baramuli, D., \& Irfan A.B. 2011. Revitalisasi filantropi Islam. URL: goo.gl/XQoubl. Last accessed on 27 March 2016.

Clarke, P. J. 2002. Accounting for managing. Cork, IE: Oak Tree Press.

Claver, E., Llopis, J., Reyes Gonzalez, M., \& Gascó, J.L. 2001. The performance of information systems through organizational culture. Information Technology \& People, 14(3): 247-260. DOI: 10.1108/09593840110402149

Colquit, J.A., Lepine J.A., \& Wesson M.J. 2011. Organizational behavior: Improving performance and commitment in the workplace. New York, NY: McGraw Hill/Irwin.

Gellinas, Jr., Ulrich, J., Dull, R.B., \& Wheeler P. R. 2012. Accounting information system. Mason, USA: South Western Cengage Learning.

Griffin, R.W., \& Moorhead, G. 2003. Organizational behavior: Managing people and organizations. South Western, US: Nelson Education.

Hall, J.A. 2011. Accounting information system. OH; USA: South-Western Cengage Learning.

Heidmann, M., Schäffer, U., \& Strahringer, S. 2008. Exploring the role of management accounting systems in strategic sense- $\quad$ making. Information Systems Management, 25(3): 244-257. DOI: 10.1080/10580530802151194

Ivancevich, J.M., Konopaske, R.M., \& Michael, T. 2011. Organizational behavior and management. New Yo rk, NY: McGraw Hill.

Junaidi, M. 2016. Pemerintah sebut potensi zakat di Indonesia melalui. URL: goo.gl/wyuHI6. Last accessed on 27 March 2016.

Kahn, B.K., Strong, D.M., \& Wang, R.Y. 2002. Information quality benchmarks: Product and service performance. Communiof the ACM, 45(4): 184-192. DOI: 10.1145/505248.506007

Komala, A.R. 2012. pengaruh budaya organisasi terhadap sistem informasi akuntansi dan dampaknya terhadap kualinformasi akuntansi pada lembaga pengelola zakat di Bandung. Paper presented at the Seminar Nasional Akun- tansi dan Bisnis, Universitas Widyatama, Bandung, ID.

Komala, A.R. 2012. The influence of the accounting managers' knowledge and the top managements' support on the ac- counting information system and its impact on the quality of accounting information: A case of zakat institutions in Bandung. Journal of Global Management, 4(1): 53-73.

Komala, A.R. 2015. Accounting information system at the organizatioan of national zakat management. Paper pre- sented at the International Conference on Applied Informatioan and Communicatioan Technology, Universitas Komputer Indonesia, Bandung, ID.

Kreitner, R.D., \& Kinicki, A. 2009. Organizational behavior. New York. N.Y: McGraw-Hill International Edition. 
Kurniawati, E.P. , \& MeilianaIntani, A. 2016. Effect analysis of the use of accounting information, managerial performance and employee performance To wards SMEs. Journal of Administrative \& Business Studies, 2(3): 130-142.

Laudon, K.C., \& Laudon J.P. 2008. Management information systems managing the digital firm. New Yo rk, N.Y: Pear- $\quad$ son Prentice Hall.

Leidner, D.E., \& Kayworth, T. 2006. Review: A review of culture in information systems research: toward a theory of in- $\quad$ formation technology culture conflict. MIS Quarterly, 30(2): 357-399.

Mcleod, R., \& Schell, G.P. 2007. Management information systems. Upper Saddle River, N.J: Pearson/Prentice Hall.

Mcshane, L.S., \& Glinow, M.A.V . 2010. Organization behavior: Emerging knowledge and practice for the real world. New York, NY: McGraw-Hill Companies.

Moller, N., Charles, D., \& Sohail, C. 2011. Re-conceptualizing enterprise information systems. Paper presented at the 5th IFIP WG 8.9 Working Conference, Aalborg, DK.

Nana, M. 2011. Membangun kepercayaan publik dan kapasitas pengelolaan zakat di Indonesia. URL: goo.gl/cHv6SU. Last accessed on 27 March 2016.

Nevizond, C. 2007. Profil budaya organisasi, mendiagnosa budaya dan merangsang perubahannya. Bandung, ID: Penerbit Alfa Beta.

Norman, T. 2007. Integrated security systems design: Concepts, design and implementation. Burlington, MA: Elsevier Inc Jordan Hill.

O’Brien, J., \& Marakas, G.M. 2009. Management information system. New York, NY: McGraw-Hill Inc.

Romney, M.B., \& Steinbart, P. J. 2012. Accounting information system. England, UK: Pearson Education Limited.

Sajady, H., Dastgir, M., \& Nejad, H.H. 2008. Evaluation of the effectiveness of accounting information systems. International Journal of Information Science \& Technology, 6(2): 1-12.

Salehi, M., \& Abdipour, A. 2011. A study of the barriers of implementation of accounting information system: Case of listed companies in Te hran Stock Exchange. Journal of Economics \& Behavioral Studies, 2(2): 76-85.

DOI: $10.5539 /$ ijef.v2n2p186

Salehi, M., Rostami, V., \& Mogadam, A. 2010. Usefulness of accounting information system in emerging economy: Empirical evidence of Iran. International Journal of Economics \& Finance, 2(2): 186-189.

Strong, D.M., Lee, Y.W., \& Wang, R.Y. 2007. 10 potholes in the road to information quality. Cybersquare, MA: IEEE.

Susanto, A. 2004. Sistem informasi akuntansi konsep dan pengembangan berbasis komputer. Lingga Jaya, ID: Edisi Per- dana.

Tavana, M. 2011. Managing adaptability, intervention and people in enterprice information system. Hershey, USA: In- formation Science Reference.

Weyandt, J.J., Kimmel, P. D., \& Kieso, D.E. 2010. Accounting principle. Hoboiken New Jersey, NJ: John Willey \& Sons Inc. Xu, H. 2009. Data quality issues for accounting information systems' implementation: Systems, stakeholders, and organizafactors. Journal of Technology Research, 1(1): 1-7. 